\title{
Inhibitory Effect Evaluation of Glycerol-Iron Oxide Thin Films on Methicillin-Resistant Staphylococcus aureus
}

\author{
C. L. Popa, ${ }^{1}$ A. M. Prodan, ${ }^{2,3,4}$ P. Chapon, ${ }^{5}$ C. Turculet, ${ }^{2,3}$ and D. Predoi ${ }^{1}$ \\ ${ }^{1}$ National Institute of Materials Physics, P.O. Box MG 07, 077125 Magurele, Romania \\ ${ }^{2}$ Emergency Hospital Floreasca Bucharest, 8 Calea Floresca, Sector 1, 014461 Bucharest, Romania \\ ${ }^{3}$ Carol Davila University of Medicine and Pharmacy, 8 Eroii Sanitari, Sector 5, 050474 Bucharest, Romania \\ ${ }^{4}$ Department of Science and Engineering of Oxide Materials and Nanomaterials, Faculty of Applied Chemistry and Materials Science, \\ University Politehnica of Bucharest, 1-7 Polizu Street, P.O. Box 12-134, 011061 Bucharest, Romania \\ ${ }^{5}$ Horiba Jobin Yvon S.A, 16-18 rue du Canal, 91165 Longjumeau Cedex, France \\ Correspondence should be addressed to D. Predoi; dpredoi@gmail.com
}

Received 30 April 2015; Revised 24 August 2015; Accepted 6 September 2015

Academic Editor: Aiping Chen

Copyright (C) 2015 C. L. Popa et al. This is an open access article distributed under the Creative Commons Attribution License, which permits unrestricted use, distribution, and reproduction in any medium, provided the original work is properly cited.

\begin{abstract}
The main purpose of this study was to evaluate the inhibitory effect of glycerol- iron oxide thin films on Methicillin-Resistant Staphylococcus aureus (MRSA). Our results suggest that glycerol-iron oxide thin films could be used in the future for various biomedical and pharmaceutical applications. The glycerol-iron oxide thin films have been deposited by spin coating method on a silicon (111) substrate. The structural properties have been studied by X-ray diffraction (XRD) and scanning electron spectroscopy (SEM). The XRD investigations of the prepared thin films demonstrate that the crystal structure of glycerol-iron oxide nanoparticles was not changed after spin coating deposition. On the other hand, the SEM micrographs suggest that the size of the glyceroliron oxide microspheres increased with the increase of glycerol exhibiting narrow size distributions. The qualitative depth profile of glycerol-iron oxide thin films was identified by glow discharge optical emission spectroscopy (GDOES). The GDOES spectra revealed the presence of the main elements: $\mathrm{Fe}, \mathrm{O}, \mathrm{C}, \mathrm{H}$, and $\mathrm{Si}$. The antimicrobial activity of glycerol-iron oxide thin films was evaluated by measuring the zone of inhibition. After 18 hours of incubation at $37^{\circ} \mathrm{C}$, the diameters of the zones of complete inhibition have been measured obtaining values around $25 \mathrm{~mm}$.
\end{abstract}

\section{Introduction}

During the last decade, iron oxide nanoparticles such as magnetite $\left(\mathrm{Fe}_{3} \mathrm{O}_{4}\right)$ and/or maghemite $\left(\gamma\right.$ - $\left.\mathrm{Fe}_{2} \mathrm{O}_{3}\right)$, with various coatings and diameters of $3-30 \mathrm{~nm}$, have been used in biological applications [1] for diagnostics and/or cancer treatment. Recently, functionalized magnetic nanoparticles have been applied in a range of new biomedical and diagnostic applications such as magnetic resonance imaging (MRI), contrast agents [2, 3], targeted drug delivery [4], molecular biology [5], DNA purification [6], cell separation [7], and hyperthermia therapy [8].

The biocompatibility and low toxicity of functionalized iron oxide magnetic nanoparticles [9-11] with different biopolymers are crucial parameters for various applications.

Two of the phases of iron oxides, $\mathrm{Fe}_{3} \mathrm{O}_{4}$ and $\gamma-\mathrm{Fe}_{2} \mathrm{O}_{3}$, present a major interest in numerous applications due to their particular magnetic properties and because iron oxide nanoparticles consist of nontoxic elements several new researches have focused on iron oxide thin films [12].

In previous studies, the growth of hematite $\left(\alpha-\mathrm{Fe}_{2} \mathrm{O}_{3}\right)$ thin films by reactive evaporation of iron in an oxygen atmosphere [13] was reported. Akl [14] in her studies on optical properties of crystalline and noncrystalline iron oxide thin films deposited by spray pyrolysis showed that the film structure changed from noncrystalline to crystalline at the same substrate temperature. Moreover, Akl [14] demonstrated that the effect of substrate temperature as well as the deposition time can influence the optical properties, with the optical constants being dependent on the film thickness and independent of the growth temperature. Previous studies have proved that nanoparticles can contribute to bactericidal effects [15]. According to Taylor and Webster [16], iron oxide nanoparticles may bring some supplementary 
benefits for biofilm treatment. In their studies on the use of superparamagnetic nanoparticles (SPION) for prosthetic biofilm prevention, they showed that SPION can be used for numerous anti-infection orthopedic applications [16].

The spin coating method used to deposit glycerol-iron oxide thin films is a simple, inexpensive technique and a promising candidate for obtaining biocompatible surfaces for potential applications in the medical field. The specific characteristics of nanoscale iron oxides particles were determined in order to use them in a variety of different applications. On the other hand, glycerol is a natural antimicrobial agent and a common ingredient found in food and cosmetics. According to Projan et al. [17], low concentrations of glycerol can inhibit various staphylococci. Moreover, recent studies [18] have shown that the monolaurate glycerol can inhibit growth of Candida and Gardnerella vaginalis bacterial strains in vitro and in vivo, inhibiting the signal transduction at microbial plasma membranes.

This study also reports the preparation and characterization of glycerol-iron oxide layer. Firstly, we synthesized glycerol stabilized with iron oxide nanoparticles in normal atmospheric conditions by coprecipitation method. Secondly, glycerol-iron oxide thin films were prepared by spin coating deposition. The glycerol-iron oxide nanoparticles and glycerol-iron oxide thin films were characterized by $\mathrm{X}$ Ray diffraction (XRD) and scanning electron microscopy (SEM). The qualitative chemical analysis of the glycerol-iron oxide thin films was evaluated by glow discharge optical emission spectroscopy (GDOES). Finally the inhibitory effect of glycerol-iron oxide layer on methicillin-resistant Staphylococcus aureus (MRSA) was investigated.

\section{Experimental Section}

2.1. Thin Film of Glycerol Coated Iron Oxide. Ferrous chloride tetrahydrate $\left(\mathrm{FeCl}_{2} \cdot 4 \mathrm{H}_{2} \mathrm{O}\right)$, ferric chloride hexahydrate $\left(\mathrm{FeCl}_{3} \cdot 6 \mathrm{H}_{2} \mathrm{O}\right)$, chlorhydric acid $(\mathrm{HCl})$, natrium hydroxide $(\mathrm{NaOH})$, and ammonia $\left(\mathrm{NH}_{3}\right)$ were purchased from Merck Glycerol. $\mathrm{C}_{3} \mathrm{H}_{8} \mathrm{O}_{3}$, (99.5\%) was purchased from Sigma. Deionized water was used in the synthesis of nanoparticles and in the rinsing of clusters. The $\varnothing 6^{\prime \prime}$ Silicon Wafer, Type $\mathrm{P} /\langle 100\rangle$, was purchased from TED PELLA, INC. Microscopy Products for Science and Industry.

The glycerol-iron oxide nanoparticles (GIO) were synthetized by coprecipitation method in air at room temperature. The ferric and ferrous chlorides (molar ratio 2:1) were prepared by dissolving $0.30 \mathrm{M}$ of $\mathrm{FeCl}_{3} \cdot 6 \mathrm{H}_{2} \mathrm{O}$ and $\mathrm{FeCl}_{2} \cdot 4 \mathrm{H}_{2} \mathrm{O}$ in $60 \mathrm{~mL}$ of $\mathrm{HCl}(0.16 \mathrm{M})[19,20]$. The resulting solution was added drop by drop into $200 \mathrm{~mL}$ of $\mathrm{NaOH}(1 \mathrm{M})$ containing $50 \mathrm{~mL}$ glycerol. The suspension was vigorously stirred for $1 \mathrm{~h}$ and heated another $2 \mathrm{~h}$ at $80^{\circ} \mathrm{C}$. Glycerol coated magnetic iron oxide nanoparticles were purified by ultrafiltration after centrifugation at $10000 \mathrm{rpm}$ for $60 \mathrm{~min}$. The resulted glycerol-iron oxide nanoparticles were redispersed in ethanol solutions containing $25 \mathrm{~mL}$ (GIO-1) and $50 \mathrm{~mL}$ (GIO-2) glycerol under vigorous stirring. Finally, one milliliter of the solution was pipetted onto the substrate (commercially pure $\mathrm{Si}$ ), and the substrate was spun at $1000 \mathrm{rpm}$ for
$30 \mathrm{~s}$. The resulting films were annealed in air at $60^{\circ} \mathrm{C}$ for $2 \mathrm{~h}$ immediately after coating and then heated at $100^{\circ} \mathrm{C}$ for $1 \mathrm{~h}$ in vacuum to remove excess solvent and to further densify the film [9].

2.2. Characterization Methods. The samples were characterized for phase content by X-ray diffraction (XRD) with a Bruker D8-Advance X-ray diffractometer in the scanning range $25-70^{\circ}$ using $\mathrm{Cu} \mathrm{K} \alpha(1.5416 \AA)$ incident radiation. The morphology of the material was studied using a Quanta Inspect $\mathrm{F}$ scanning electron microscope (SEM). The top surface analysis of the samples was studied by Glow Discharge Optical Emission Spectroscopy (GDOES) [21, 22] using a GD Profiler 2 from Horiba/Jobin-Yvon. The technique is suitable for thin film analysis and permits determining the chemical gradient composition from the surface to the bulk and, if the ablation rate can be estimated, to determine the thickness of different layers of the nanocomposite materials $[23,24]$.

Methicillin-resistant Staphylococcus aureus (MRSA) bacterial strain was obtained from Polymed Medical Center, Bucharest, Romania. The MRSA strain used in this study was isolated from an abdominal wound after right hemicolectomy. The MRSA strain clinically isolated is believed to be most representative for this type of bacteria. The bacteria were cultured at $37^{\circ} \mathrm{C}$ in blood agar with $5 \%$ sheep blood and a chromogen agar medium CPS3 (Biomerieux Franta). The final working concentration was of $1 \times 10^{6} \mathrm{CFU} \mathrm{mL}^{-1}$. MRSA was typed with the latex agglutination assay Slidex Staphylococcus Detection (no. 73117, Biomerieux, Marcy l'Etoile, France) using a cefoxitin disk [25] according to [26]. For this strain a resistance profile was determined using the Kirby-Bauer method with multidisc (Bio-Rad, DF, Mexico) and CLSI guide 2014 edition.

\section{Results and Discussions}

The XRD investigations of dried GIO nanoparticles are illustrated in Figure 1. Based on XRD data refinement, the GIO nanoparticles synthesized by coprecipitation method showed characteristic peaks which are assigned to the (220), (311), (400), (422), (511), and (440) reflections of the mixture of the spinel phases maghemite $\left(\gamma-\mathrm{Fe}_{2} \mathrm{O}_{3}\right)$ and magnetite $\left(\mathrm{Fe}_{3} \mathrm{O}_{4}\right)$. The proportion of the two phases was calculated by Rietveld refinement for the GIO nanoparticles. The maghemite $(a=$ $0.835 \mathrm{~nm}$ ) was found in proportion of $91.9116 \% \pm 0.119$ while the magnetite $(a=0.840 \mathrm{~nm})$ was found in proportion of $8.0884 \% \pm 0.236$. According to previous studies [27] it should be noted that the standard XRD patterns of $\left(\gamma-\mathrm{Fe}_{2} \mathrm{O}_{3}\right)$ and $\left(\mathrm{Fe}_{3} \mathrm{O}_{4}\right)$ are difficult to distinguish. The calculated mean size of the nanoparticles was about $7.7 \pm 0.023 \mathrm{~nm}$.

SEM analysis was used to observe the morphology of GIO nanoparticles and GIO thin films (GIO-1 and GIO2). In Figure 2 the SEM image of GIO nanoparticles is presented. The SEM image shows that the glycerol coated iron oxide nanoparticles are spherical and their average diameter is about $9 \pm 1 \mathrm{~nm}$. Therefore, the average size of the nanoparticles deduced by SEM investigations is in good agreement with XRD analysis. 


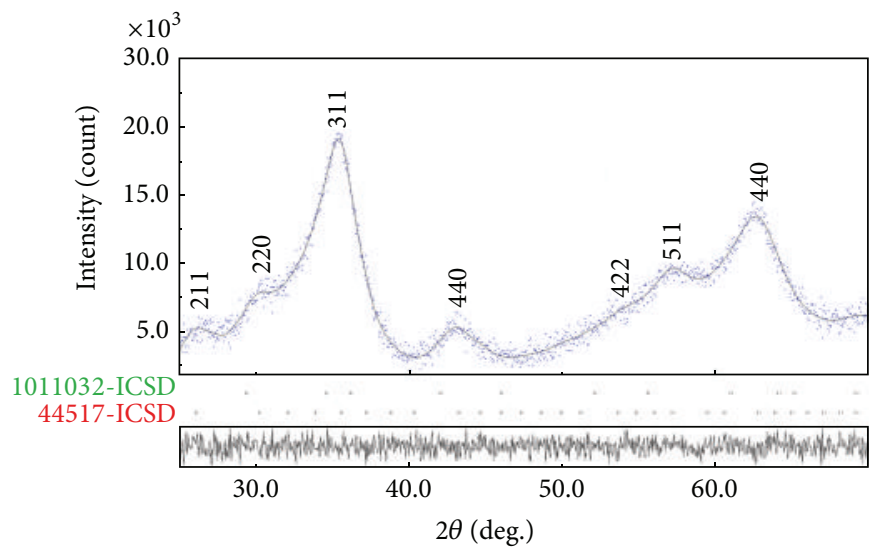

FIGURE 1: Experimental (blue), calculated (solid line gray), and difference plots (lover line) of the glycerol coated iron oxide nanoparticles (mixture of the spinel phases $\gamma$ - $\mathrm{Fe}_{2} \mathrm{O}_{3}$ (44517-ICSD) and magnetite $\mathrm{Fe}_{3} \mathrm{O}_{4}$ (1011032-ICSD)).

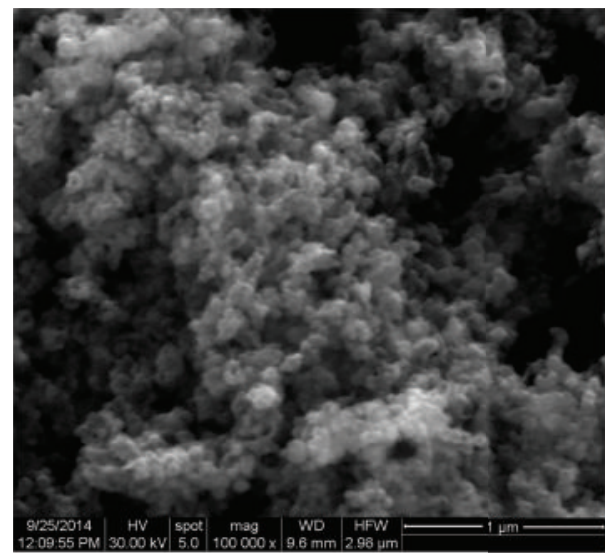

Figure 2: SEM image of the glycerol coated iron oxide nanoparticles.

The XRD patterns of GIO-1 and GIO-2 thin films are also similar and conserve the structure of GIO nanoparticles (Figure 3). The reflections were assigned to the spinel phases $\left(\gamma-\mathrm{Fe}_{2} \mathrm{O}_{3}\right.$ magnetite $\left.\mathrm{Fe}_{3} \mathrm{O}_{4}\right)$. The sizes of GIO-1 and GIO2 thin films were calculated by Sherrer's formula [28]. The average particle sizes of GIO-1 and GIO-2 thin films were estimated to be $18.7 \pm 1 \mathrm{~nm}$ and $24.8 \pm 1 \mathrm{~nm}$, respectively, deduced from the position of characteristic peaks assigned to the (311), (400), (511), and (440) reflections.

The XRD investigations of GIO-1 and GIO-2 thin films demonstrated that the crystal structure of GIO nanoparticles does not change after spin coating deposition.

The morphology and mean nanoparticle diameters of GIO thin films (GIO-1 and GIO-2) are illustrated in Figure 4. The SEM images of GIO thin films (GIO-1 and GIO-2) show a homogenous surface structure. The sizes of the glycerol-iron oxide microspheres obtained on the thin film surfaces exhibit a narrow size distribution (Figure 4). After acquiring SEM micrographs on different areas of the two thin films (GIO-1 and GIO-2), statistical histograms have been performed. These histograms showed that the mean nanoparticle diameters have values around $19.9 \pm 0.07 \mathrm{~nm}$ for

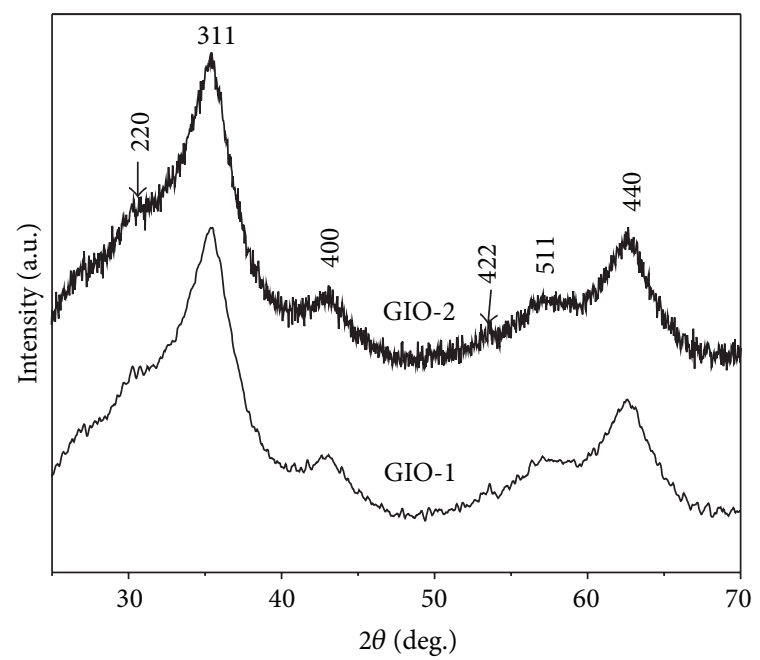

FIGURE 3: X-ray diffraction patterns of GIO-1 and GIO-2 thin films.

the GIO-1 thin film (Figure 4(c)) and around $23.9 \pm 0.11 \mathrm{~nm}$ for the GIO-2 thin film (Figure 4(d)).

Furthermore, the size of the spherical microspheres increases with the increase of glycerol amount (GIO-2).

Glow discharge optical emission spectroscopy (GDOES) is an atomic emission spectrometer system that can be used mainly to analyze elemental composition of solids, liquids, and gases [29]. In our studies, the GDOES method was used for qualitative determination of the constituent elements in the films. According to Jakubéczyová et al. [30], from the concentration profiles it is possible to approximately deduce the layer thickness. However, errors are to be expected in this type of recalculation. Moreover, Vnouček [31] in her studies on "Povrchové efekty při GDOES (Surface Effects at GDOES)" affirms that there is no universal way for the elimination of these inaccuracies and it is necessary to carry out individual calibrations. Similarly, Payling et al. [32] in their studies showed that depth calculation from GDOES measurements is the result of several steps, "each bringing potential uncertainties." 


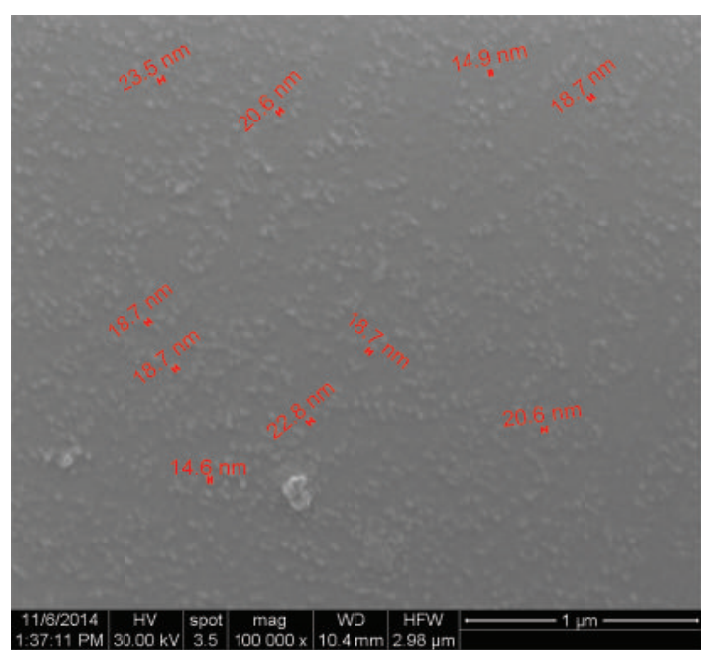

(a)

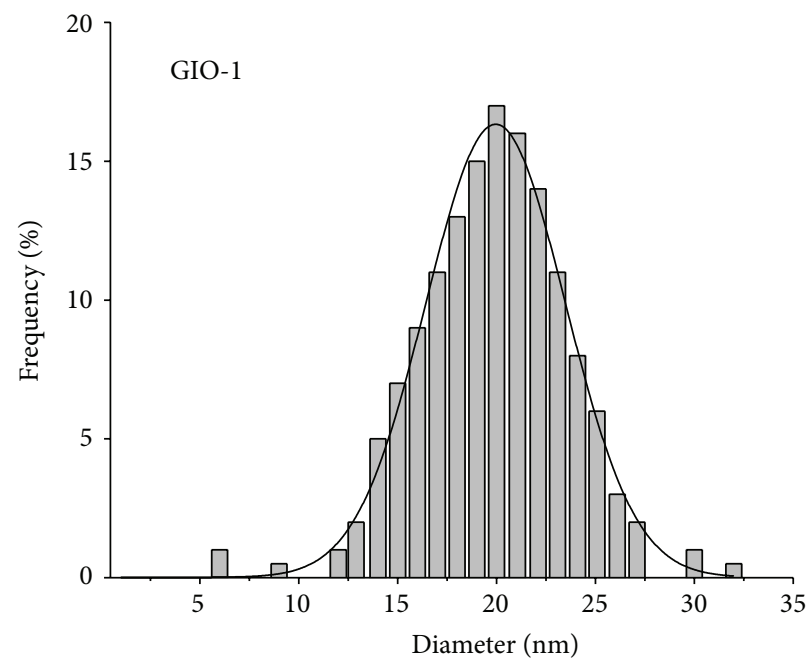

(c)

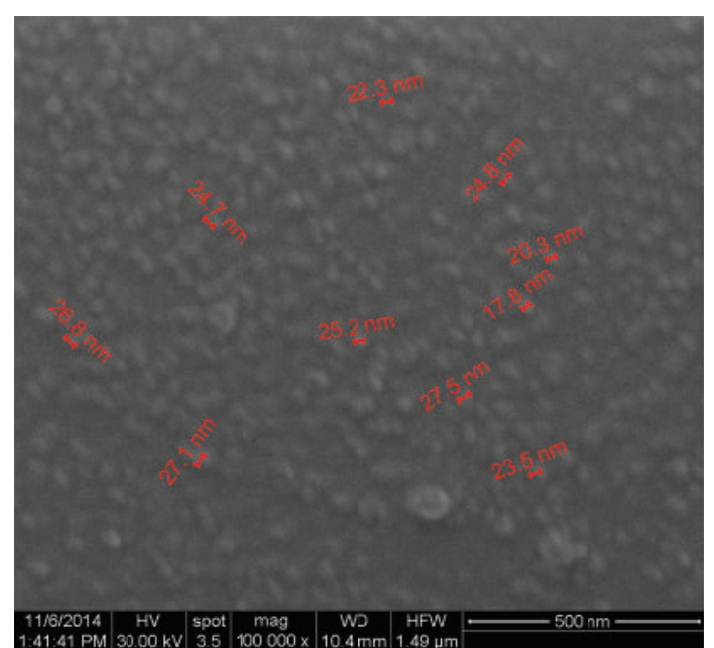

(b)

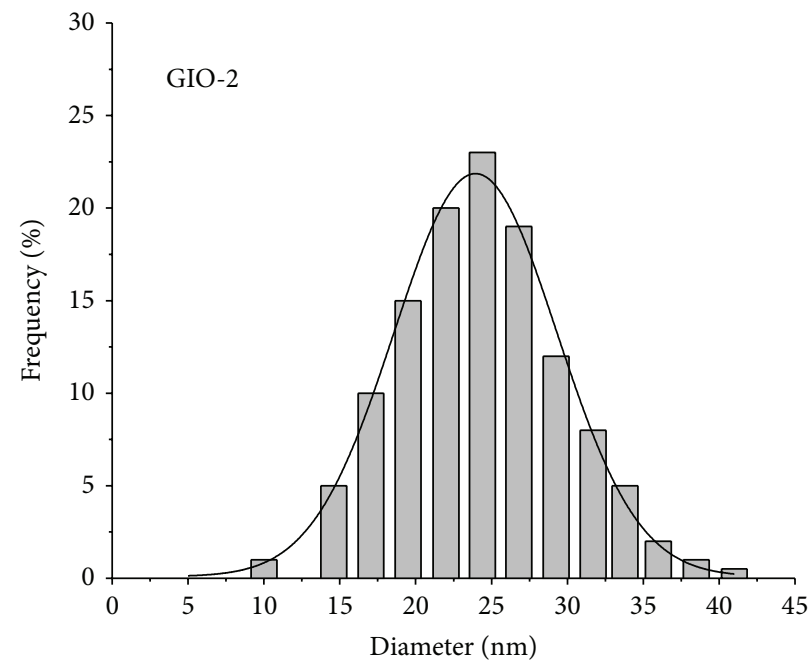

(d)

FIGURE 4: SEM images of GIO-1 (a) and GIO-2 (b) thin films. The mean nanoparticle diameters of GIO-1 (c) and GIO-2 (d) thin films.

The elemental distribution from coating to substrate with glycerol-iron oxide nanoparticles was investigated using GDOES depth profile. GDOES spectra were acquired for thin films of glycerol-iron oxide nanoparticles dispersed in ethanol solution containing $25 \mathrm{~mL}$ (GIO-1) and $50 \mathrm{~mL}$ (GIO2) glycerol under vigorous stirring and deposited on a pure $\mathrm{Si}$ substrate (Figure 5).

The results shown in Figure 5 reveal the distribution of the main elements of the coating and substrate along the depth direction including $\mathrm{Fe}, \mathrm{O}, \mathrm{C}, \mathrm{H}$, and $\mathrm{Si}$. Interpretation is not easy but it is clear that the oxygen content increased at the top surface of the GIO-1 and GIO-2 thin films and the iron content remained constant up to a certain depth for the coating obtained for the two layers. Also, the carbon and hydrogen contents were higher in the coating obtained from glycerol-iron oxide nanoparticles dispersed in the ethanol solution containing $50 \mathrm{~mL}$ glycerol (GIO-2). From Figure 5 we also observe that the GIO-2 profile exhibits higher silicon concentrations compared to GIO-1 profile, while the oxygen concentration is slightly higher for GIO-1 compared to the GIO-2; this might be linked to the coverage of the layer on $\mathrm{Si}$ over the sputtered area $(4 \mathrm{~mm})$.

The objective of our study was to investigate the antibacterial activity of glycerol-iron oxide thin films (GIO-1 and GIO2) on Methicillin-Resistant Staphylococcus aureus bacterial strain. The second substrate, from Figure 6(B), is faded because the glycerol-iron oxide ratio is greater than the one used in Figure 6(A). The increase of the amount of glycerol in the sample leads to a discoloration of the solution used for layer deposition. The antimicrobial activity of glycerol-iron oxide thin films was evaluated in triplicate by measuring the zone of inhibition after 18 hours of incubation at $37^{\circ} \mathrm{C}$. After incubation, the diameters of the zones of complete inhibition (seen with the naked eye) were measured. Around glyceroliron oxide thin films onto commercially pure $\mathrm{Si}$ substrate we can see the bright inhibition zones indicating the antibacterial activity (Figure 6). The antibacterial activity increased from $22 \pm 1 \mathrm{~mm}$ (Figure 6(A)) to $27 \pm 1 \mathrm{~mm}$ (Figure 6(B)). 

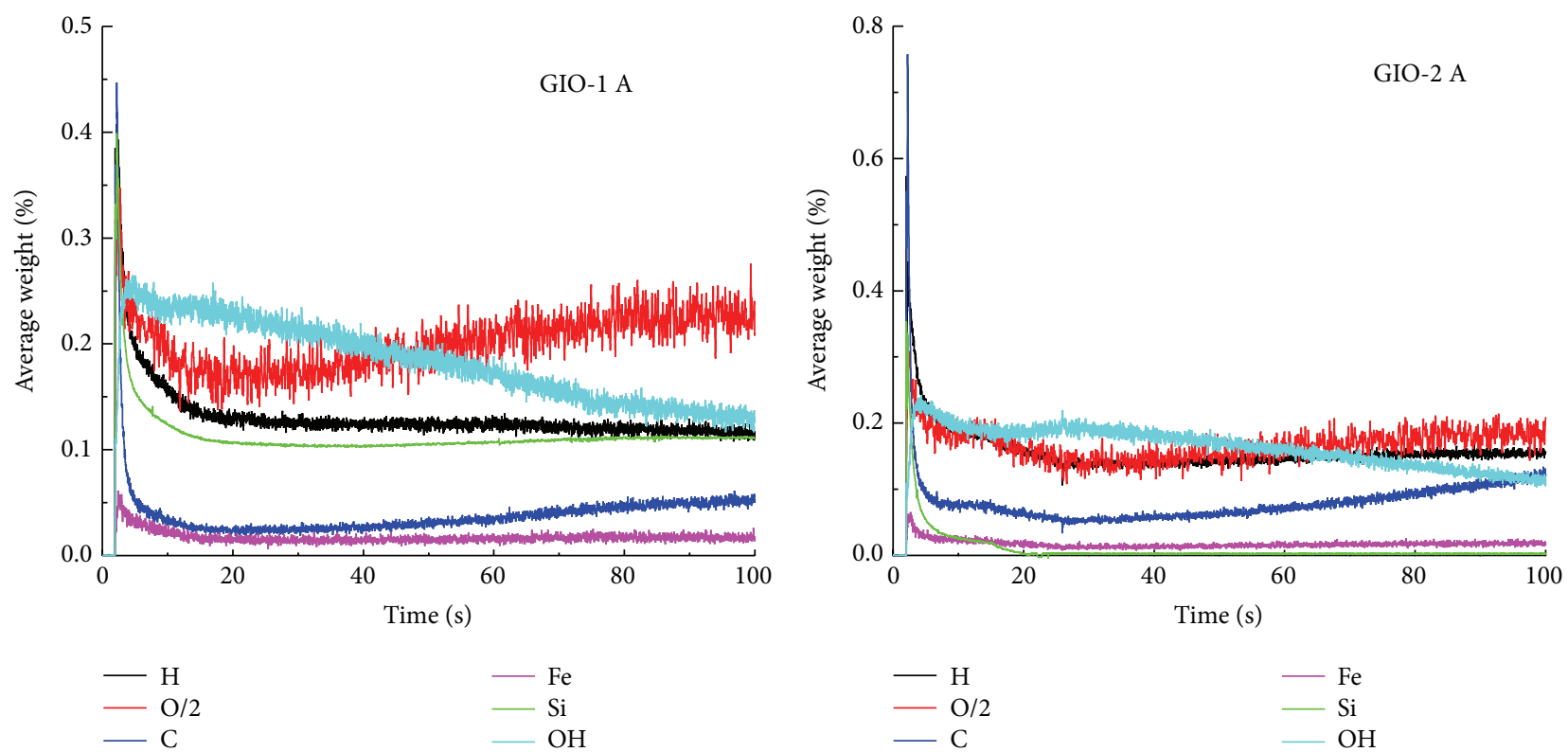

(a)

(b)
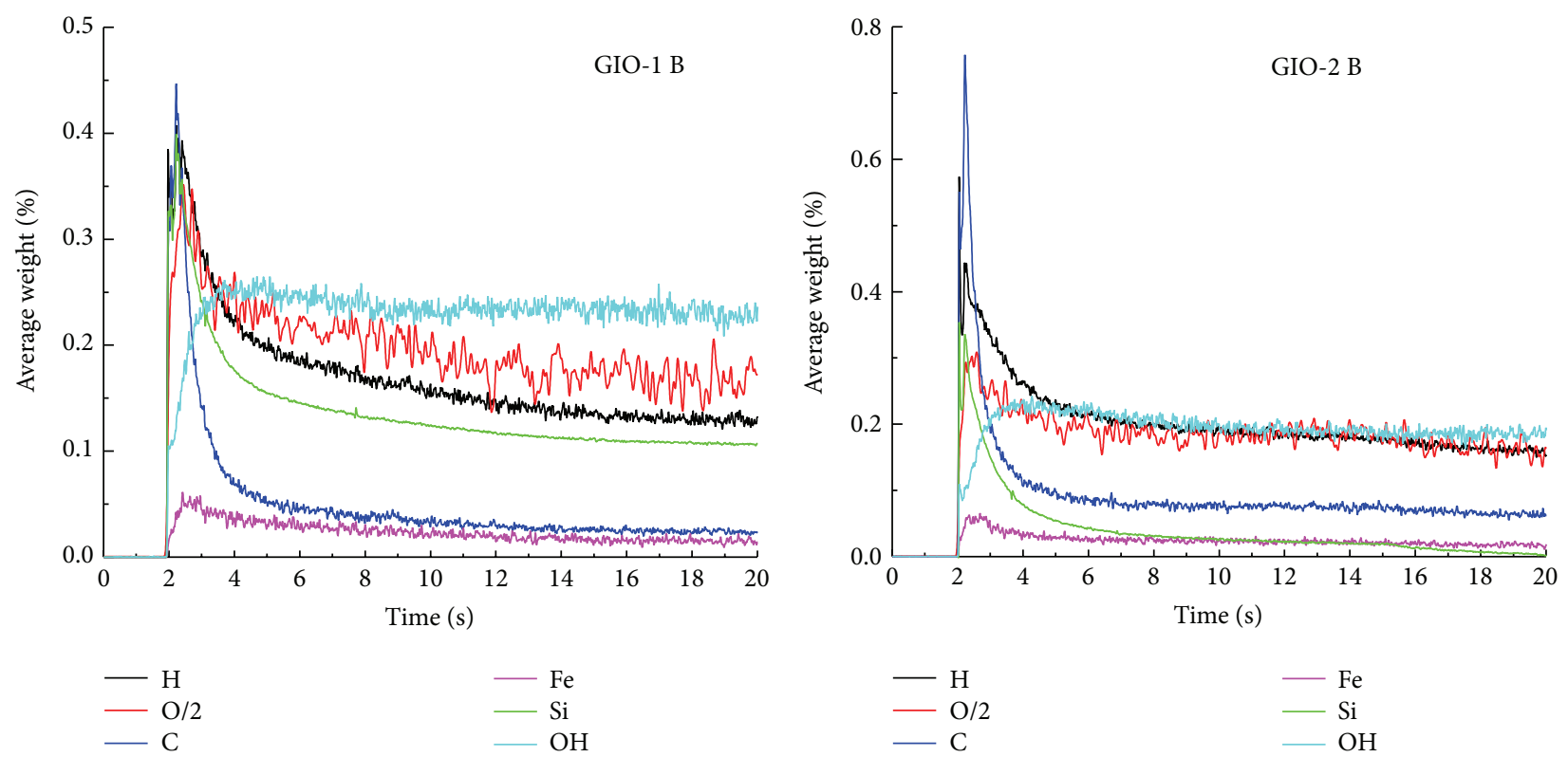

(c)

(d)

FIGURE 5: Typical GDOES composition depth profiles of GIO-1 A and GIO-2 A thin films after dispersion of glycerol-iron oxide nanoparticles in ethanol solution containing $25 \mathrm{~mL}$ and $50 \mathrm{~mL}$ glycerol under vigorous stirring. The GIO-1 B and GIO-2 B show zoomed in time regions $0-20 \mathrm{~s}$.

The values of antibacterial activity diameter of the three samples utilized in the study of antimicrobial activity of glycerol-iron oxide thin films are presented in Table 1.

To highlight the antimicrobial effect of GIO thin films, the GIO thin films deposited on commercially pure Si (100) were exposed to the MRSA. After 2, 4, 6, 12, and $24 \mathrm{~h}$ the suspension was collected. After collection, the suspension was incubated on agar medium for $24 \mathrm{~h}$. More than that, the number of colonies forming units per milliliter $(\mathrm{CFU} / \mathrm{mL})$ was established. In Figure 7 the antimicrobial effect depending on the time of contact with the surface of the GIO thin films for MRSA was presented.

After $24 \mathrm{~h}$ a drastic decrease of the MRSA CFU for the two samples (GIO-1 and GIO-2 thin films) was noticed. As you can see in Figure 7, the antimicrobial effect occurs just $2 \mathrm{~h}$ after the time of contact with the surface of GIO-1 and GIO-2 thin films with MRSA. After $6 \mathrm{~h}$ of contact with the surface of GIO-1 thin films, the CFU of MRSA decreased linearly up to $24 \mathrm{~h}$. For the GIO-2 thin films, the antimicrobial effect increased linearly in time between 0 and $24 \mathrm{~h}$. After $24 \mathrm{~h}$, 

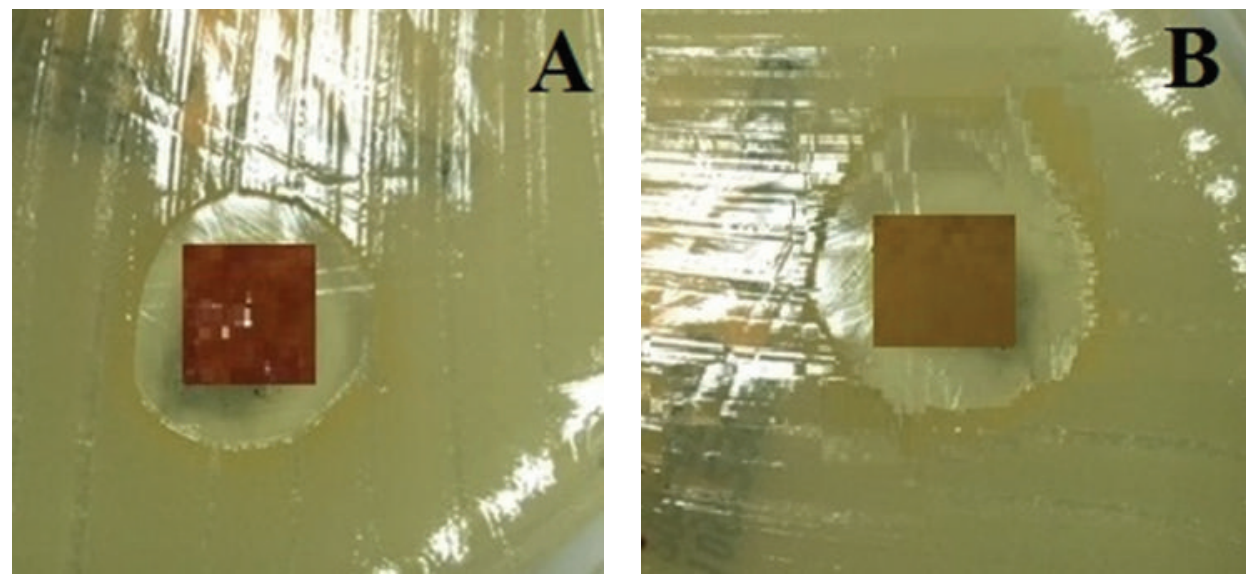

FIGURE 6: Antibacterial activity of glycerol-iron oxide thin films on Methicillin-resistant Staphylococcus aureus bacterial strain. A: GIO-1; B: GIO-2.

TABLE 1: The values of antibacterial activity diameter of the three samples utilized for antimicrobial evaluation.

\begin{tabular}{lcccc}
\hline Sample & $\begin{array}{c}\text { Diameter of the } \\
\text { complete inhibition } \\
\text { zones }(D 1)\end{array}$ & $\begin{array}{c}\text { Diameter of the } \\
\text { complete inhibition } \\
\text { zones }(D 2)\end{array}$ & $\begin{array}{c}\text { Diameter of the } \\
\text { complete inhibition } \\
\text { zones }(D 3)\end{array}$ & $\begin{array}{c}\text { Mean diameter of the } \\
\text { complete inhibition } \\
\text { zones }(\widetilde{D})\end{array}$ \\
\hline GIO-1 & $21.6 \mathrm{~mm}$ & $23.4 \mathrm{~mm}$ & $21 \mathrm{~mm}$ & $22 \mathrm{~mm}$ \\
GIO-2 & $25.8 \mathrm{~mm}$ & $25.9 \mathrm{~mm}$ & $29.3 \mathrm{~mm}$ & $27 \mathrm{~mm}$ \\
\hline
\end{tabular}

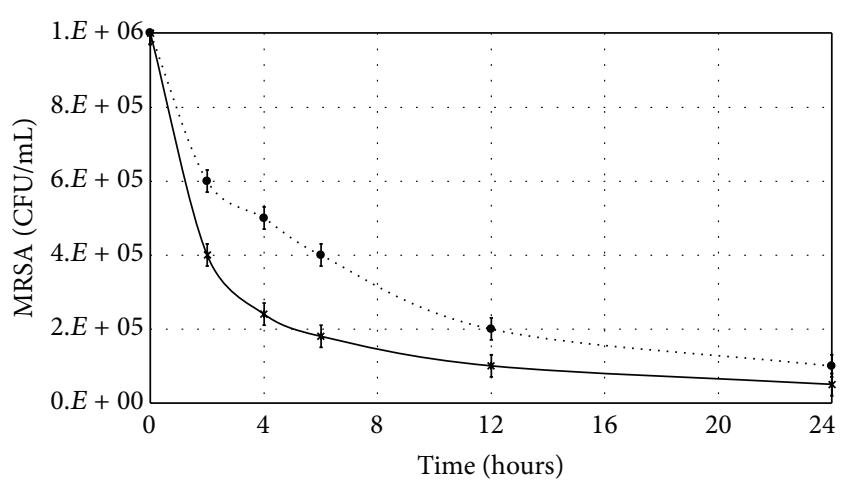

* GIO-1

•.. GIO-2

FIgURE 7: The antimicrobial effects depending on the time of contact with the surface of GIO thin films.

the number of MRSA CFU approached to zero. According to the experimental results of the antibacterial studies, the survival bacteria are meaningfully reduced when the amount of glycerol increased. The generation of $\mathrm{OH}$ could be the reason why the antimicrobial effectiveness of glycerol layer of iron oxide increased when the amount of glycerol increased.

It is well known that in recent years nanotechnology has made major progress. Thus, different types of metals and metal oxides at the nanoscale with antimicrobial properties were obtained [33-37]. Due to their low toxicity to humans and their antimicrobial activity, silver nanoparticles have been intensively investigated $[34,38]$. More recently, the first studies on antimicrobial silver doped hydroxyapatite were reported by Ciobanu et al. $[39,40]$. Iron oxide nanoparticles have been widely used in biomedical research areas due to their special magnetic properties, their surface properties, and their biocompatibility. A major challenge is represented by the production of a magnetic drug delivery system in which magnetic nanoparticles coated with drugs can be directed to infection sites by an external magnetic field [41]. Along this line, we try to find an alternative treatment based only on iron oxide nanoparticles, without the use of antibiotics. Touati [42] in his research on iron and oxidative stress in bacteria showed that reactive oxygen species (ROS) generated by magnetite nanoparticles could kill bacteria without killing healthy cells (cells nonaffected by the bacteria). Our present study on the evaluation of the inhibitory effect of glycerol-iron oxide layer on MRSA bacterial strain could be included in the common effort to find alternative solutions to antibiotics for the treatment or prevention of microbial infections.

The results of our studies are in good agreement with previous studies conducted by Saegeman et al. [43]. In the study on short- and long-term bacterial inhibiting effect of high concentrations of glycerol used in the preservation of skin allografts [43] it was shown that glycerol certainly induces bacteriostasis. Poirier et al. [44] have demonstrated that a prolonged stay at a specific activity of the water activity, $a_{w}$ (measure of the amount of unbound water that is freely available for microorganisms), is not supported by bacteria. This could demonstrate the bacterial inhibition effect of glycerol because most organisms cannot cope with a low specific water activity $a_{w}$. Moreover, Mille et al. [45] showed that glycerol solutions reduce the water content necessary for the bacterial cells. 
According to the results presented in this research, it can be concluded that the glycerol-iron oxide thin films possess antimicrobial properties against MRSA bacterial strain. It can be stated that the glycerol-iron oxide layer could be used in the medical field to prepare a new antimicrobial product.

\section{Conclusions}

In this research, the glycerol-iron oxide thin films were obtained simply by spin coating deposition method on a silicon (111) substrate. The XRD patterns of glycerol-iron oxide thin films conserve the structure of glycerol coated iron oxide nanoparticles. The structure of glycerol-iron oxide thin films is homogenous and the size of the spherical microspheres increases with the increase of glycerol amount. The GDOES spectra performed on glycerol-iron oxide thin films reveal the distribution of the main elements $\mathrm{Fe}, \mathrm{O}$, $\mathrm{C}, \mathrm{H}$, and $\mathrm{Si}$. The thickness of thin films has been affected by the concentration of glycerol in the glycerol-iron oxide nanoparticles solution.

MRSA bacterial strain presented an inhibition zone which increased when the glycerol amount in the samples increased. In addition, the glycerol-iron oxide thin films showed better antibacterial performance when the amount of glycerol increased. In conclusion, we can say that the present research proposes a new antimicrobial product that could be used for various medical applications involving inhibition of antibiotic-resistant bacteria.

\section{Conflict of Interests}

The authors declare that they have no competing interests.

\section{Acknowledgments}

This research was financially supported by the Ministry of Education of Romania, Project no. 131/2014. Also thework has been funded by the Sectoral Operational Programme Human Resources Development 2007-2013 of the Ministry of European Funds through the Financial Agreement POSDRU/159/1.5/S/134398.

\section{References}

[1] U. Häfeli, W. Schütt, J. Teller, and M. Zborowski, Scientific and Clinical Applications of Magnetic Carriers, Springer, New York, NY, USA, 1997.

[2] L. M. Lacava, Z. G. M. Lacava, M. F. Da Silva et al., "Magnetic resonance of a dextran-coated magnetic fluid intravenously administered in mice," Biophysical Journal, vol. 80, no. 5, pp. 2483-2486, 2001.

[3] L. Babes, B. Denizot, G. Tanguy, J. J. Le Jeune, and P. Jallet, "Synthesis of iron oxide nanoparticles used as MRI contrast agents: a parametric study," Journal of Colloid and Interface Science, vol. 212, no. 2, pp. 474-482, 1999.

[4] S. M. Moghimi, A. C. Hunter, and J. C. Murray, "Longcirculating and target-specific nanoparticles: theory to practice," Pharmacological Reviews, vol. 53, no. 2, pp. 283-318, 2001.
[5] M. A. Bogoyevitch, T. S. Kendrick, D. C. H. Ng, and R. K. Barr, "Taking the cell by stealth or storm? Protein Transduction Domains (PTDs) as versatile vectors for delivery," DNA and Cell Biology, vol. 21, no. 12, pp. 879-894, 2002.

[6] M. Uhlen, "Magnetic separation of DNA," Nature, vol. 340, no. 6236, pp. 733-734, 1989.

[7] I. Safarık and M. J. Safarıkova, "Use of magnetic techniques for the isolation of cells," Journal of Chromatography B, vol. 722, no. 1-2, pp. 33-53, 1999.

[8] A. Jordan, R. Scholz, K. Maier-Hauff et al., "Presentation of a new magnetic field therapy system for the treatment of human solid tumors with magnetic fluid hyperthermia," Journal of Magnetism and Magnetic Materials, vol. 225, no. 1-2, pp. 118-126, 2001.

[9] S. L. Iconaru, E. Andronescu, C. S. Ciobanu, A. M. Prodan, P. le Coustumer, and D. Predoi, "Biocompatible magnetic iron oxide nanoparticles doped dextran thin films produced by spin coating deposition solution," Digest Journal of Nanomaterials and Biostructures, vol. 7, no. 1, pp. 399-409, 2012.

[10] E. Andronescu, M. Costache, C. S. Ciobanu, A. M. Prodan, and D. Predoi, "Synthesis and characterization of bio-compatible maghemite nanoparticles," Digest Journal of Nanomaterials and Biostructures, vol. 5, no. 3, pp. 779-786, 2010.

[11] E. Andronescu, C. S. Ciobanu, L. Pall, M. Costache, and D. Predoi, "Preliminary biocompatibility studies of hydroxyapatite coated iron oxide," Romanian Journal of Materials, vol. 40, no. 3, pp. 242-249, 2010.

[12] D. Predoi, C. S. Ciobanu, M. Radu et al., "Hybrid dextran-iron oxide thin films deposited by laser techniques for biomedical applications," Materials Science and Engineering C, vol. 32, no. 2, pp. 296-302, 2012.

[13] M. F. Al-Kuhaili, M. Saleem, and S. M. A. Durrani, "Optical properties of iron oxide $\left(\alpha-\mathrm{Fe}_{2} \mathrm{O}_{3}\right)$ thin films deposited by the reactive evaporation of iron," Journal of Alloys and Compounds, vol. 521, pp. 178-182, 2012.

[14] A. A. Akl, "Optical properties of crystalline and non-crystalline iron oxide thin films deposited by spray pyrolysis," Applied Surface Science, vol. 233, no. 1-4, pp. 307-319, 2004.

[15] S. S. Behera, J. K. Patra, K. Pramanik, N. Panda, and H. Thatoi, "Characterization and evaluation of antibacterial activities of chemically synthesized iron oxide nanoparticles," World Journal of Nano Science and Engineering, vol. 2, no. 4, pp. 196-200, 2012.

[16] E. N. Taylor and T. J. Webster, "The use of superparamagnetic nanoparticles for prosthetic biofilm prevention," International Journal of Nanomedicine, vol. 4, pp. 145-152, 2009.

[17] S. J. Projan, S. Brown-Skrobot, P. M. Schlievert, F. Vandenesch, and R. P. Novick, "Glycerol monolaurate inhibits the production of beta-lactamase, toxic shock toxin-1, and other staphylococcal exoproteins by interfering with signal transduction," Journal of Bacteriology, vol. 176, no. 4, pp. 4204-4209, 1994.

[18] K. L. Strandberg, M. L. Peterson, Y.-C. Lin, M. C. Pack, D. J. Chase, and P. M. Schlievert, "Glycerol monolaurate inhibits Candida and Gardnerella vaginalis in vitro and in vivo but not Lactobacillus," Antimicrobial Agents and Chemotherapy, vol. 54, no. 2, pp. 597-601, 2010.

[19] E. H. Kim, Y. Ahn, and H. S. Lee, "Biomedical applications of superparamagnetic iron oxide nanoparticles encapsulated within chitosan," Journal of Alloys and Compounds, vol. 434-435, pp. 633-636, 2007.

[20] B. Gaihre, S. Aryal, N. A. M. Barakat, and H. Y. Kim, "Gelatin stabilized iron oxide nanoparticles as a three dimensional 
template for the hydroxyapatite crystal nucleation and growth," Materials Science and Engineering C, vol. 28, no. 8, pp. 12971303, 2008.

[21] J. Malherbe, B. Fernández, H. Martinez, P. Chapon, P. Panjan, and O. F. X. Donard, "In-depth profile analysis of oxide films by radiofrequency glow discharge optical emission spectrometry (rf-GD-OES): possibilities of depth-resolved solid-state speciation," Journal of Analytical Atomic Spectrometry, vol. 23, no. 10, pp. 1378-1387, 2008.

[22] M. Wilke, G. Teichert, R. Gemma et al., "Glow discharge optical emission spectroscopy for accurate and well resolved analysis of coatings and thin films," Thin Solid Films, vol. 520, no. 5, pp. 1660-1667, 2011.

[23] M. V. Barbosa, G. Hammes, C. Binder, A. N. Klein, and J. D. B. De Mello, "Physicochemical characterisation of tribolayers by micro-Raman and GDOES analyses," Tribology International, vol. 81, pp. 223-230, 2014.

[24] S. M. Barinov, J. V. Rau, S. N. Cesaro et al., "Carbonate release from carbonated hydroxyapatite in the wide temperature rage," Journal of Materials Science: Materials in Medicine, vol. 17, no. 7, pp. 597-604, 2006.

[25] Department of Health and Human Services. Centers for Disease Control, "Detection of Oxacillin/Methicillin-resistant Staphylococcus aureus," April 2008, http://www.cdc.gov/ncidod/dhqp/ ar_lab_mrsa.html.

[26] N. V. Ayala-Núñez, H. H. L. Villegas, L. del Carmen Ixtepan Turrent, and C. Rodríguez Padilla, "Silver nanoparticles toxicity and bactericidal effect against methicillin-resistant staphylococcus aureus: Nanoscale does matter," Nanobiotechnology, vol. 5, no. 1-4, pp. 2-9, 2009.

[27] G. Schimanke and M. Martin, "In situ XRD study of the phase transition of nanocrystalline maghemite $\left(\gamma-\mathrm{Fe}_{2} \mathrm{O}_{3}\right)$ to hematite $\left(\alpha-\mathrm{Fe}_{2} \mathrm{O}_{3}\right)$," Solid State Ionics, vol. 136-137, pp. 1235-1240, 2000.

[28] H. P. Klug and L. E. Alexander, X-Ray Diffraction Procedures for Polycrystalline and Amorphous Materials, John Wiley \& Sons, New York, NY, USA, 1962.

[29] T. K. Rout, "Nanolayered oxide on a steel surface reduces surface reactivity: evaluation by glow discharge optical emission spectroscopy (GDOES)," Scripta Materialia, vol. 56, no. 7, pp. 573-576, 2007.

[30] D. Jakubéczyová, P. Hvizdoš, and M. Selecká, "Investigation of thin layers deposited by two PVD techniques on high speed steel produced by powder metallurgy," Applied Surface Science, vol. 258, no. 12, pp. 5105-5110, 2012.

[31] M. Vnouček, Surface effects at GDOES [Ph.D. Study Work], University of West Bohemia, Pilsen, Czech Republic, 2002 (Czech).

[32] R. Payling, D. G. Jones, and A. Bengston, Glow Discharge Optical Emission Spectrometry, John Wiley \& Sons, New York, NY, USA, 1997.

[33] P. K. Stoimenov, R. L. Klinger, G. L. Marchin, and K. J. Klabunde, "Metal oxide nanoparticles as bactericidal agents," Langmuir, vol. 18, no. 17, pp. 6679-6686, 2002.

[34] A. D. Russell and W. B. Hugo, "Antimicrobial activity and action of silver," in Progress in Medicinal Chemistry, vol. 31, chapter 7, pp. 351-370, Elsevier, 1994.

[35] C. S. Ciobanu, S. L. Iconaru, M. C. Chifiriuc, A. Costescu, P. Le Coustumer, and D. Predoi, "Synthesis and antimicrobial activity of silver-doped hydroxyapatite nanoparticles," BioMed Research International, vol. 2013, Article ID 916218, 10 pages, 2013.
[36] C. S. Ciobanu, S. L. Iconaru, I. Pasuk et al., "Structural properties of silver doped hydroxyapatite and their biocompatibility," Materials Science and Engineering C, vol. 33, no. 3, pp. 13951402, 2013.

[37] A. M. Prodan, S. L. Iconaru, C. M. Chifiriuc et al., "Magnetic properties and biological activity evaluation of iron oxide nanoparticles," Journal of Nanomaterials, vol. 2013, Article ID 893970, 7 pages, 2013.

[38] J. R. Morones, J. L. Elechiguerra, A. Camacho et al., "The bactericidal effect of silver nanoparticles," Nanotechnology, vol. 16, no. 10, pp. 2346-2353, 2005.

[39] C. S. Ciobanu, F. Massuyeau, L. V. Constantin, and D. Predoi, "Structural and physical properties of antibacterial Ag-doped nano-hydroxyapatite synthesized at $100^{\circ} \mathrm{C}$," Nanoscale Research Letters, vol. 6, no. 1, article 613, 2011.

[40] C. S. Ciobanu, S. L. Iconaru, P. Le Coustumer, L. V. Constantin, and D. Predoi, "Antibacterial activity of silver doped hydroxyapatite nanoparticles against gram-positive and gram-negative bacteria," Nanoscale Research Letters, vol. 7, no. 1, pp. 324-332, 2012.

[41] N. Tran, A. Mir, D. Mallik, A. Sinha, S. Nayar, and T. J. Webster, "Bactericidal effect of iron oxide nanoparticles on Staphylococcus aureus," International Journal of Nanomedicine, vol. 5, no. 1, pp. 277-283, 2010.

[42] D. Touati, "Iron and oxidative stress in bacteria," Archives of Biochemistry and Biophysics, vol. 373, no. 1, pp. 1-6, 2000.

[43] V. S. M. Saegeman, N. L. Ectors, D. Lismont, B. Verduyckt, and J. Verhaegen, "Short- and long-term bacterial inhibiting effect of high concentrations of glycerol used in the preservation of skin allografts," Burns, vol. 34, no. 2, pp. 205-211, 2008.

[44] I. Poirier, P.-A. Maréchal, and P. Gervais, "Effects of the kinetics of water potential variation on bacteria viability," Journal of Applied Microbiology, vol. 82, no. 1, pp. 101-106, 1997.

[45] Y. Mille, L. Beney, and P. Gervais, "Viability of Escherichia coli after combined osmotic and thermal treatment: a plasma membrane implication," Biochimica et Biophysica Acta, vol. 1567, pp. $41-48,2002$. 

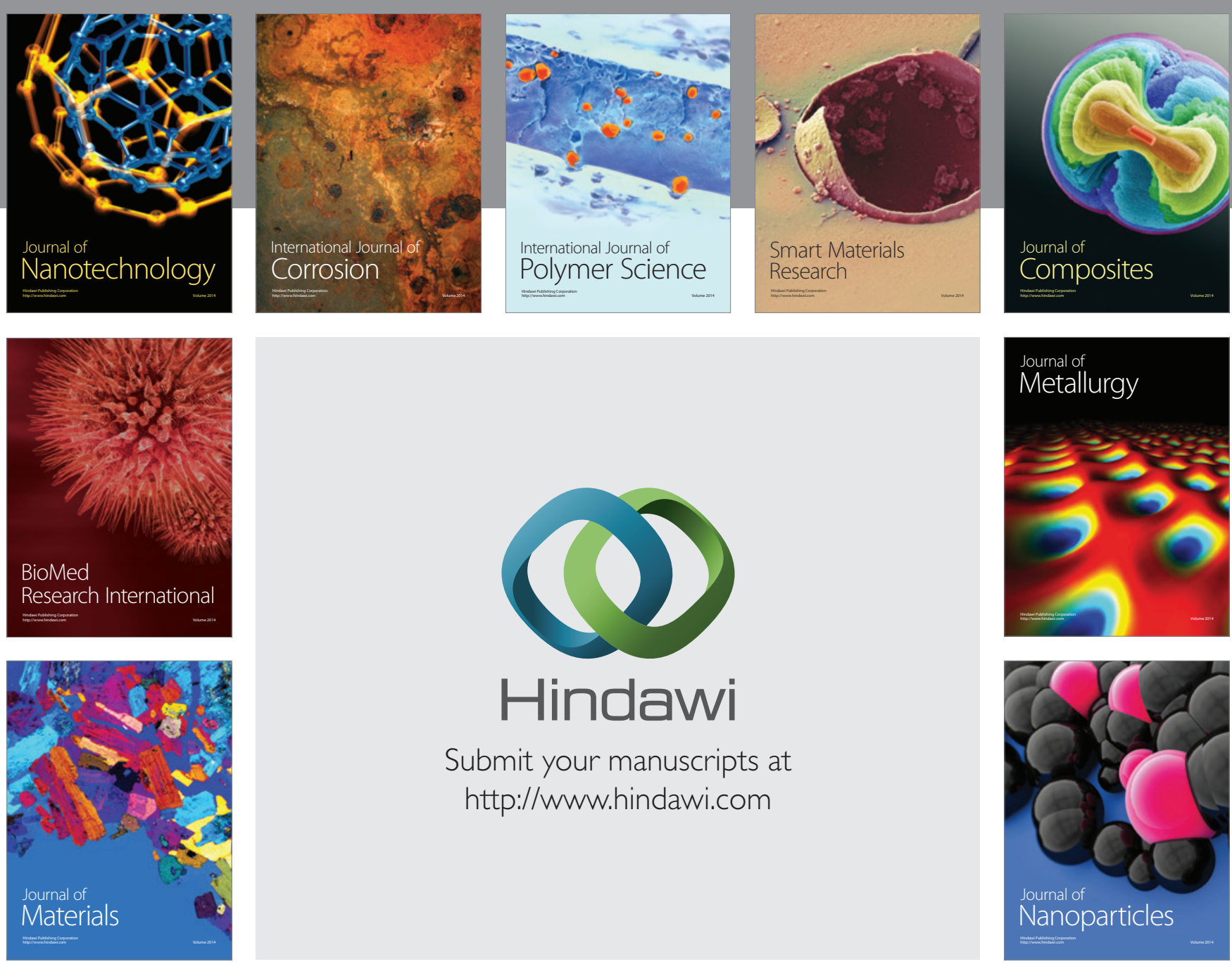

Submit your manuscripts at http://www.hindawi.com
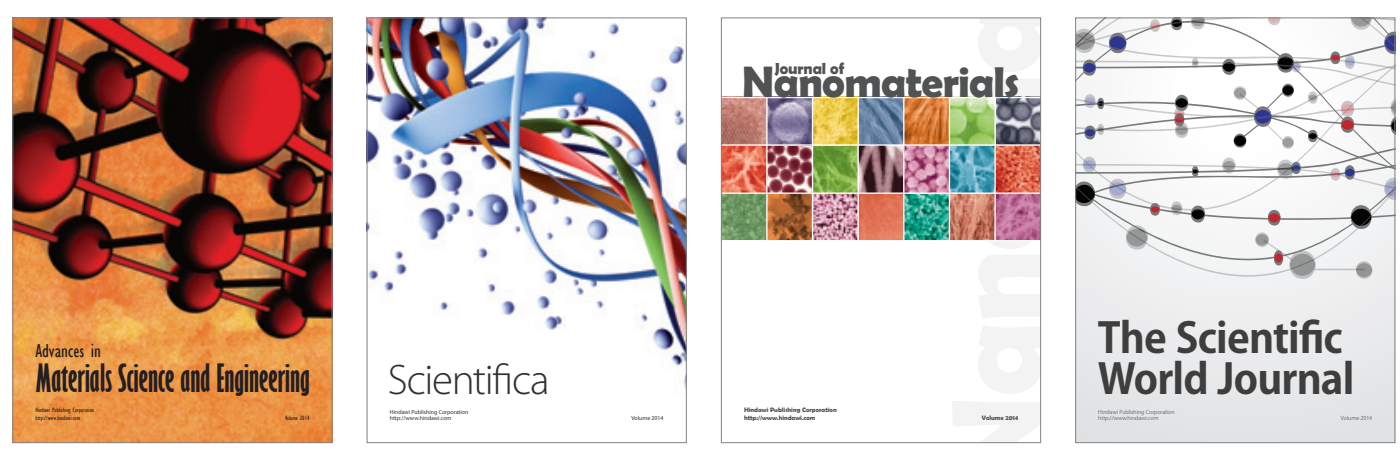

\section{The Scientific World Journal}
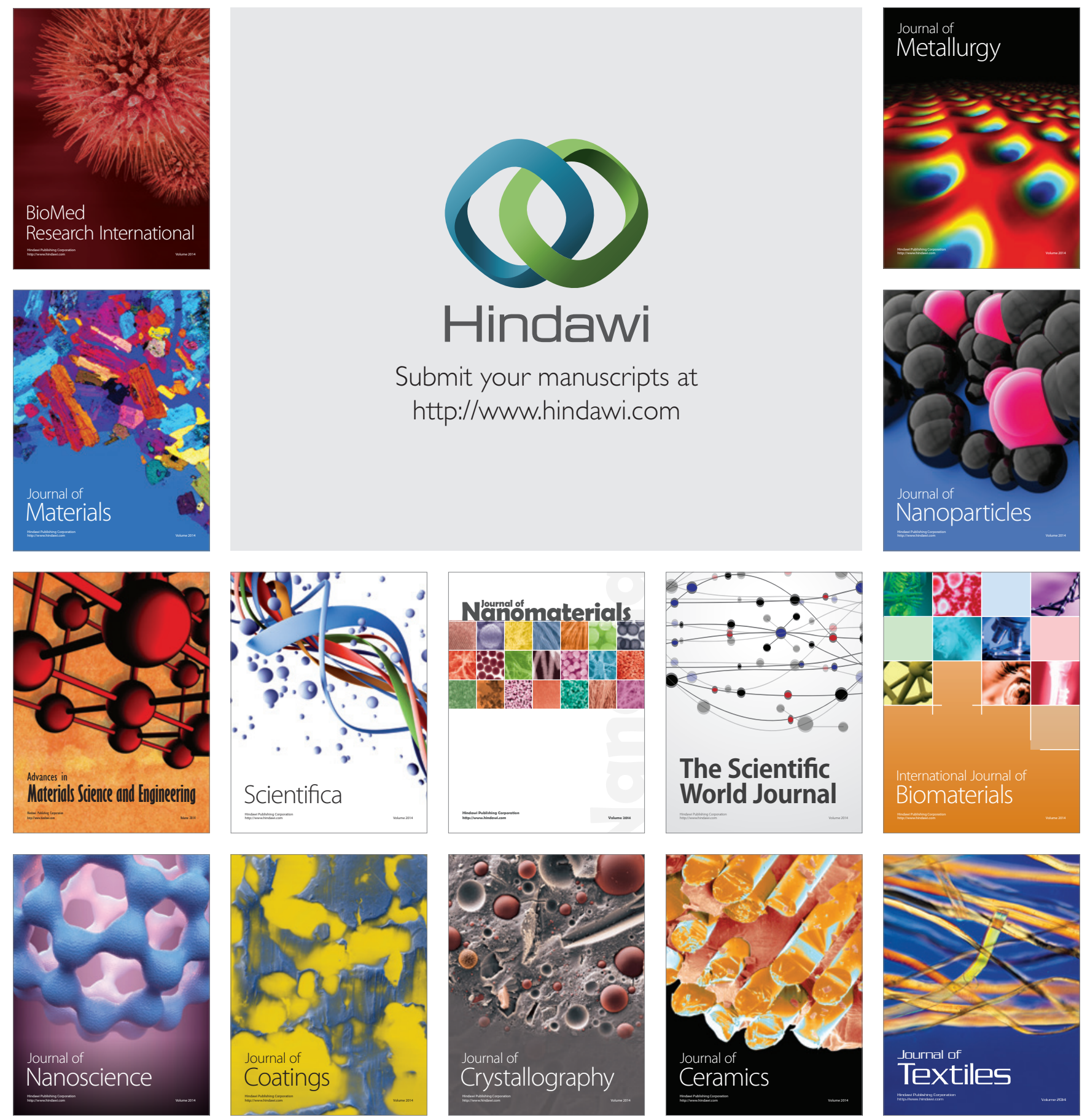